\title{
THE ROLE OF REVIEWING BUILDING STRUCTURES TO FULFILL REQUIREMENTS FOR STIFFNESS, STABILITY AND STRENGTH OF BUILDING STRUCTURES
}

\author{
Nusa Setiani Triastuti ${ }^{1}$, Indriasari ${ }^{2}$ \\ 1,2 Lecturer of Civil Engineering Department, Faculty of Engineering, \\ KrisnadwipayanaUniversity. Jl. Unkris. Jatiwaringin. Jakarta Timur \\ Telp 6221-84998529 Fax 6221-84998529 Ponsel 628161837669 \\ e-mail: nusasetiani@unkris.ac.id ${ }^{l}$; indriasari@unkris.ac.id ${ }^{2}$.
}

\begin{abstract}
Indonesia at the location of the earthquake All building structures must meet the structural requirements, namely stiffness, stability, strength. Review structures before building are built determine whether they meet the requirements Methodology Case studies based on secondary data. from the design consultant The author analyzes with the help of structure software. The purpose of this research is to make sure the building structure meets the structural requirements before it is built. The author conducted a design review based on the Indonesian Code (SNI) Desain consultant data, building structure is still twist in shape mode 1 and 2 after checking in software. Then the authors review and improve mainly dimensions, reinforcement columns and add shear walls. As a result of the addition of shear walls and column changes, the structure meets the requirements of strength, stiffness and stability. Building structure does not occur twist in shape modes 1 and 2. That is the role of design structure review before it is built. To increase the stability of the structure at the bottom of the stairs out towards the back is given a retaining wall, overcoming the horizontal direction of active soil pressure, ground water and surface water from the direction of the hill.
\end{abstract}

Keywords : Add shear wall; Changing; Column; Review structure design before build; Stability; Stiffness; Strengthening

\section{INTRODUCTION}

The building is not two-axis symmetry. The load position of the architecture plan is not symmetrical. Simetri buildings are preferred for structure design rather than irregular buildings. This is because simetri buildings tend to have a center of mass and a center of rigidity that almost same point. When an earthquake occurs, the point of capture of an earthquake's force on a building is at the center of its mass, while the resistance force carried out by the building is centered on the center of its stiffness. Many buildings that architecturally have high aesthetic value, which is generally the choice of architects in designing a building. Most of these buildings have irregular structure. To determine whether the building is safe, we need several criteria that must be met, namely stiffness, strength, and stability of the structural system.

Provision of shear walls in the CBlock Building from the campus in the indicated location will maintain the burden of the earthquake and make the building earthquake resistant. The thickness and reinforcement considered and provided for shear walls can be sufficient to take care of all types of loads developed due to earthquake (Reddy, et al, 2015)

To increase sliding wall performance: (Resmi, 2016) 
- Structure with shear walls in more suitable locations important while considering base displacement and shear.

- Shear walls with openings experienced a decrease in terms of strength

- Diagonal shear wall found effective for structures located in earthquake prone areas.

Consensus to develop structural systems with high performance seismic earthquake resistance (DRSRS) for cities that are sustainable and resilient. DRSRS system; The main conclusions are illustrated as follows: (1) Test results show that the sliding wall system with replaceable coupling beams has less earthquake post-disaster damage compared to conventional shear wall systems. The energy discharge device can be used as a part of the clutch fuse that can be replaced independently or used together with a clutch beam that can be replaced together into a sliding wall system (Venkatesh, et al, 2017).

The position of the column and the sliding wall must be centric so that there are no moments due to eccentricity, so that the upper structure is central with the bore pile according to the force that occurs in the design (Triastuti, 2017).

\section{METHODS}

Method the case study uses secondary data.

In this study comparing the columns designed by the structure designer and author because the design carried out by the structure designer shows that the results of the run of the structure software are still torsi in shape modes
1 and 2 , so it is necessary to re-design the structure.

The quality of concrete and reinforcement are used as follows

- Quality of concrete is 24,9 mpa

- Main quality steel bars is 400 mpa

- Quality steel stirrup bar is $240 \mathrm{mpa}$

The building data is in Figures 1 to 3

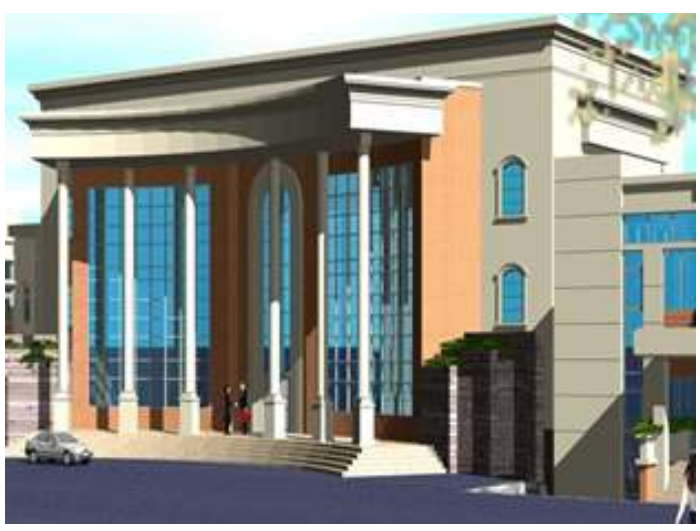

Figure 1. Front View

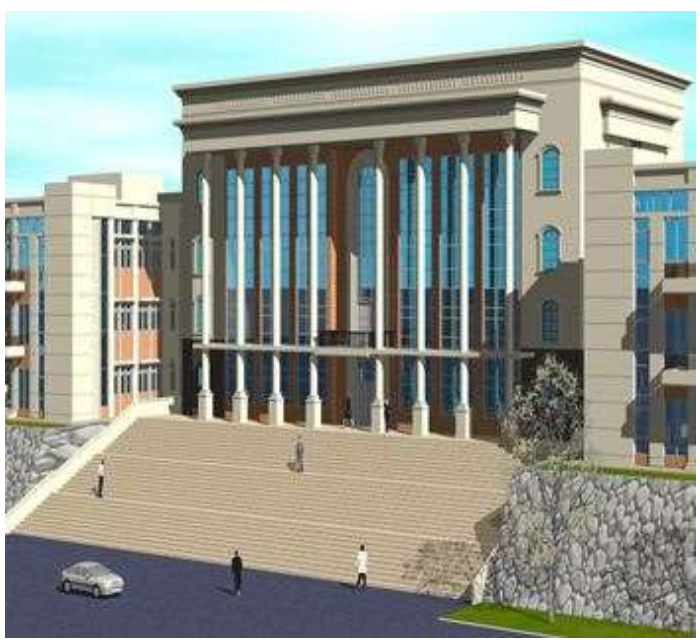

Figure 2. Back View

The bottom of the ladder is made countefort to withstand the horizontal contact force of active soil and water pressure 


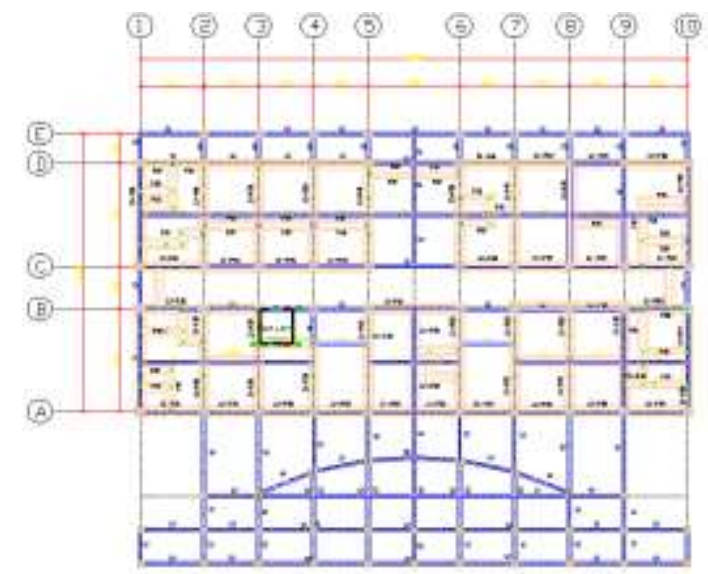

Figure 3. Structure Layout

The structure system that will be analyzed in this paper is the office building system structure in the IPSC (Indonesia Peace and Security Center) Sentul, Bogor, West Java. This building has a non-rectangular shape, so it will cause the building to easily rotate along its longitudinal axis or experience twisting. One solution used to improve the performance of multi-storey structures in this study is the installation of a shear wall. Shear wall is a reinforced concrete slab that is installed in a vertical position on the side of a particular building that serves to increase the rigidity of the structure and absorb a large shear force along with the higher structure.

1. Number of floors: 4 floors +1 roof floor

2. Building height: $18.7 \mathrm{~m}$

3. Building length: $36 \mathrm{~m}$

4. Building width: $19.5 \mathrm{~m}$

The objection of this research is to ensure the building structure meets the requirements of strength, stiffness, stability before construction

\section{Results And Discussion}

In accordance with SNI 03-17262012, which needs attention.

1. Quake Load

Structure analysis of earthquake loads refers to earthquake resistance planning standards for houses and buildings. Structural analysis of earthquake loads in buildings is done by the dynamic response spectrum analysis method.

2. Factor Important Structure (I)

The fact that the risk of office buildings II and the primacy of structures for offices in SNI 03-17262012 article 4.1 table 2 is taken at 1.

\section{Ductility Factor}

The structure of the building is included in the category of dual system structure, namely the moment retaining frame structure with reinforced concrete shear walls. Although the earthquake zone is mild, but considering the condition of the existing land and the classification of construction in the form of irregular buildings, this structure is designed as a medium moment frame system(SDMMF,term SNI is SRPMM).

SDMMF earthquake ductility and reduction factors in SNI 03-17262002 article 4.3.6 table 3, factors $\mu \mathrm{m}$ $=4$ and $\mathrm{Rm}=6.5$ are taken. With this value, the building is partial ductile ,article 7.2.2 SNI 1726-2013

$$
\begin{aligned}
& R,=5 \% \text { and } \\
& C_{b}{ }^{a}=4,5 \%
\end{aligned}
$$

\section{Determination of Soil Type}

Soil type is defined as hard soil. medium soil, or soft soil if for the maximum 30 meter thick layer is fulfilled the requirements listed in SNI 03-1726-2012 article 5.3 table 3. Soil in Sentul, Bogor, West Java is a soft soil classification of SE sites.

5. Seismic ground motion maps and risk coefficients

Based on the map of the earthquake area of Indonesia in 
SNI 1726-2012 image $9 \mathrm{~S} 1=0.3-$ $0.4 \mathrm{~g}$, Sentul Ss area $=0.9-1 \mathrm{~g}$ Figure 4 S1. An earthquake spectrum response plan for soft soil and rock acceleration map are shown in

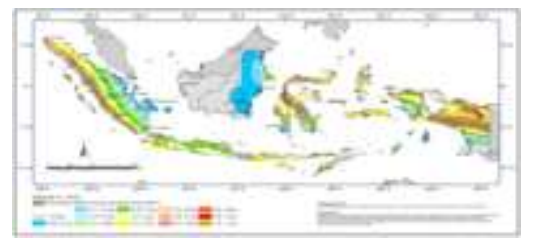

Figure 4 : An earthquake spectrum response plan for soft soil

Based on the map of the earthquake area of Indonesia in SNI 1726-2012 image $9 \mathrm{~S} 1=0.3$ $0.4 \mathrm{~g}$, Sentul Ss area $=0.9-1 \mathrm{~g}$

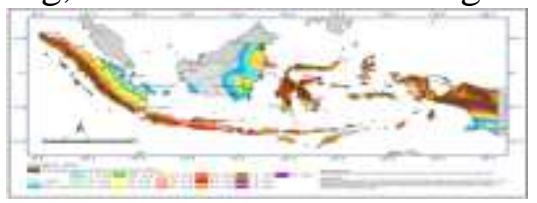

Figure 5. Rock Acceleration Map (Ss)

$\mathrm{Ss}=0,9-1 \mathrm{~g}$; $\mathrm{S} 1-0,3-0,4 \mathrm{~g}$ adjusted Rock Acceleration Map (Ss)

Spectral respond period is 0,2 seconds, Crs both 0,95-1 and 1,051,1

6. Direction of Earthquake Loading To simulate the the earthquake effect of a various directions posibility on the structure of the building, on 12.6.3.3 SNI 17262012 determined the earthquake loading in the main direction $100 \%$ together with $30 \%$ of the earthquake loading in the direction perpendicular to the main direction

7. Mass, center of mass, and center of floor stiffness

In earthquake calculation with spectrum response, earthquake load works at the center of mass of each floor and is influenced by the magnitude of the mass of each floor. Difference in the center of mass and large stiffness must be avoided so that twisting does not occur in the building structure. Calculation of mass, center of gravity, and center of stiffness of each floor of the building is calculated using the help of nonlinear ETABS v9.7.3 software. These calculations can be seen in table 1 .

Table 1. Mass, center of mass, and center of floor stiffness (kgf-cm unit

Center Mass Rigidly

\begin{tabular}{lllllll}
\hline Story & MassX & MassY & XCCM & YCCM & XCR & YCR \\
& & & & & & \\
\hline Roof & 83,1345 & 83,1345 & 1705,561 & 389,122 & 1668,879 & 591,624 \\
Roof & 717,1968 & 717,1968 & 1772,144 & 639,322 & 1760,744 & 715,938 \\
Floor & & & & & & \\
Fl.4 & 736,9678 & 736,9678 & 1744,411 & 705,971 & 1763,242 & 691,209 \\
Fl.3 $^{\text {rd }}$ & 749,8678 & 749,8678 & 1736,407 & 730,277 & 1769,715 & 636,268 \\
Fl.2 $^{\text {nd }}$ & 1008,8383 & 1008,8383 & 1739,892 & 685,623 & 1783,754 & 464,386 \\
\hline
\end{tabular}

8. Control of Structure Analysis

Results

After analyzing the 3D structure using the help of the 3 Dimensional Structure program, it is known that the installation of shear walls at determined locations, making the building structure does not experience twisting in the first and second shape modes. However, it is still necessary to check the results obtained by referring to the limitations on the earthquake calculation standards (SNI 03-17262002) and SNI 1726-2012

9. The Natural Vibrating Time The natural vibrating time of the structure can be obtained from the results of the modal analysis case in the ETABS program. The results of the analysis of the calculation of the vibrational time of the structure can be seen in table 2 . 
Table 2. Vibration time and frequency

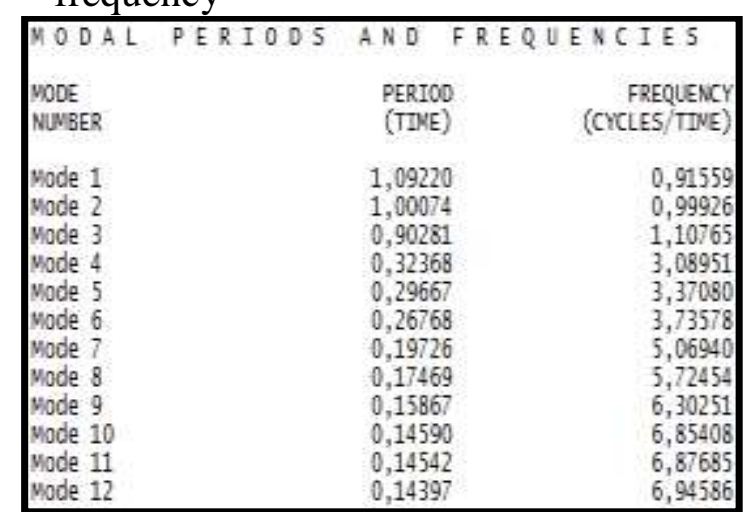

In the first vibratory range the structure obtained $\mathrm{T}$ was 1.0922, greater than the permissible time limit of vibration but under the time of vibration for a moment bearing frame structure, which states that the natural vibration time does not need to be taken greater than $\mathrm{Cu} \cdot \mathrm{Ta}$, the structure does not meet the requirements time limit of vibration time. $T_{a}=C h^{x x}$

$$
\begin{aligned}
& \mathrm{Ta}=0,0466 .(18,7) 0,9=0.650195 \\
& \mathrm{C} \text { dari table } 15=0,0466 \\
& \mathrm{~T}=0,1 \mathrm{~N}=0,5 \\
& \mathrm{~T}_{\mathrm{a}}=0,0062 \mathrm{~h}_{\mathrm{n}} \\
& \sqrt{ } C_{w}
\end{aligned}
$$

Building height 5 stories high $18.7 \mathrm{~m}$ SNI 03-1726-2002 requires that the natural vibration time should not be taken more than $n=0.19(13)=2.47$ seconds.

Whereas SNI 03-1726-2012 article 7.8.2.1, provides an empirical formula for calculating the vibration time for a moment bearing frame structure, which states that the natural vibration time does not need to be taken greater than $\mathrm{Cu} \square \mathrm{Ta}=1.4$ $(\mathrm{Ct} \square \mathrm{hnx})=1.4 \times 0.0466$ (37) $0.90=$ 1.68 seconds.

In the first vibratory range (figure 6) And the second vibratory range (figure 7.), The largest happened displacement is in the $\mathrm{x}$-direction or $\mathrm{y}$ direction and in the third vibratory range (figure 8.) The largest happened shift is twisting. The analysis shows that the structure has met the requirements of the building displacement

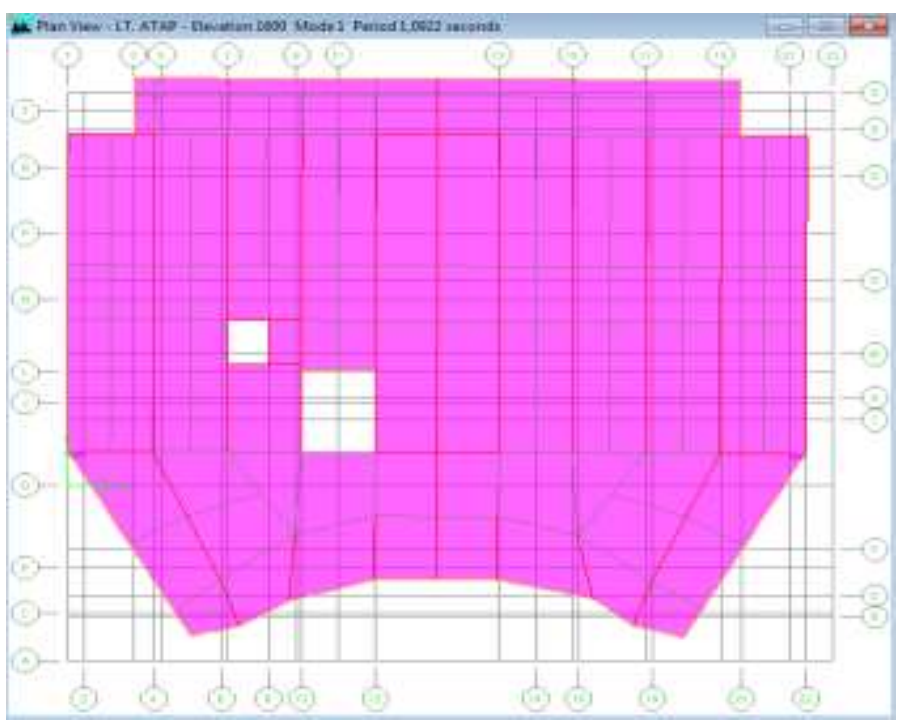

Figure 6. Mode 1 (y direction) with $\mathbf{T}=\mathbf{1 , 0 9 2 2}$ detik

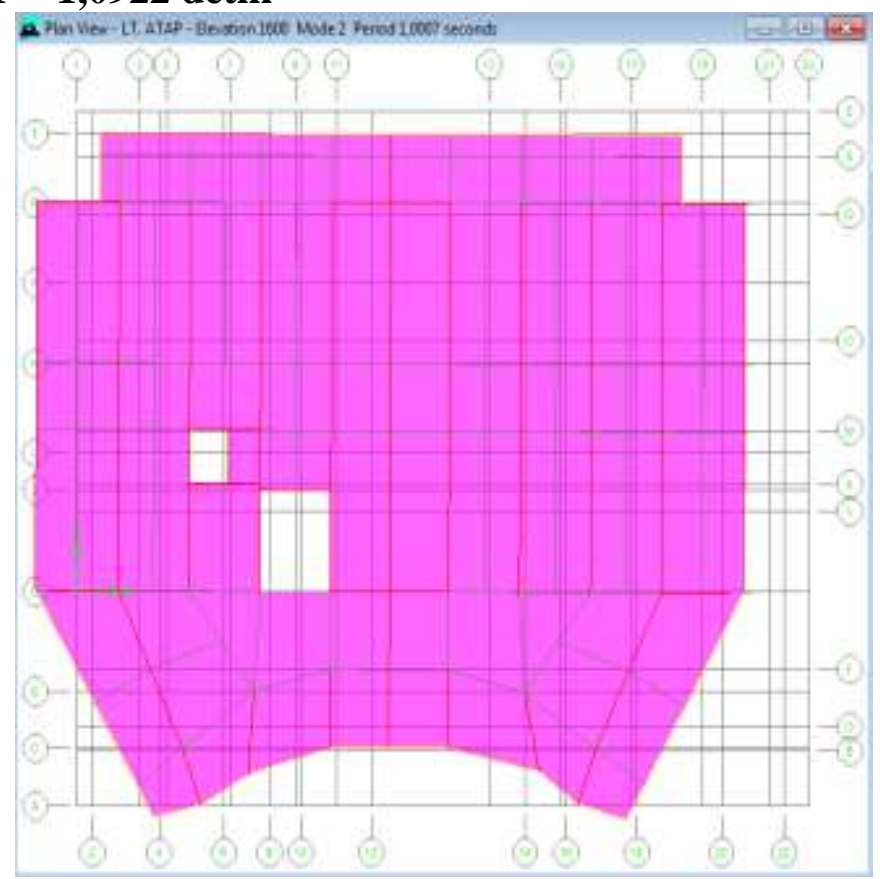

Figure 7. Mode 2 (x-direction) $T$ 1,0007 second 


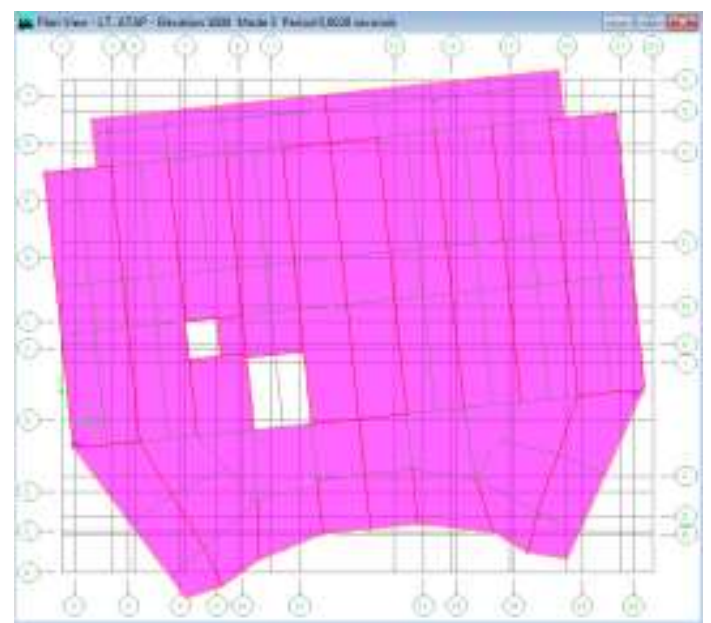

Figure 8: Mode 3 (twist) $\mathrm{T}=$ 0,9028 second

\section{Effect of P-Delta}

$\mathrm{P}$-Delta is a secondary effect acting on structural elements, which is caused by the addition of vertical loads as a result of horizontal displacement of structures. The effect of P-Delta is not required to be taken into account if the stability coefficient $(\theta)$ is less or equal to 0.1 . The stability coefficient is calculated by the formula

SNI 03-1726-2012 article 7.8.7

$$
\begin{gathered}
\Theta=\underline{P}_{\underline{x}} \frac{\mathrm{OI} I_{e}}{V_{x}} C_{s x} C_{d} \\
\Theta=\text { close to zero } 0,000609 \text {, so P } \\
\text { delta doesn't count }
\end{gathered}
$$

\section{Analysis of Variance in Response Spectrums}

Vibration range reviewed was 12 modes and effective if the percentage of dynamic loads that worked were more than 90\% (SNI 03-1726-2002 article 7.2.1.). Mass participation data from the results of the ETABS analysis can be seen in table 3 . The data shows that $90 \%$ of the mass is covered in the first 8 modes for the $\mathrm{x}$-direction and the first 7 modes for the y-direction, so the structure meets the mass participation requirements.
Table .3. Mass participation ratio

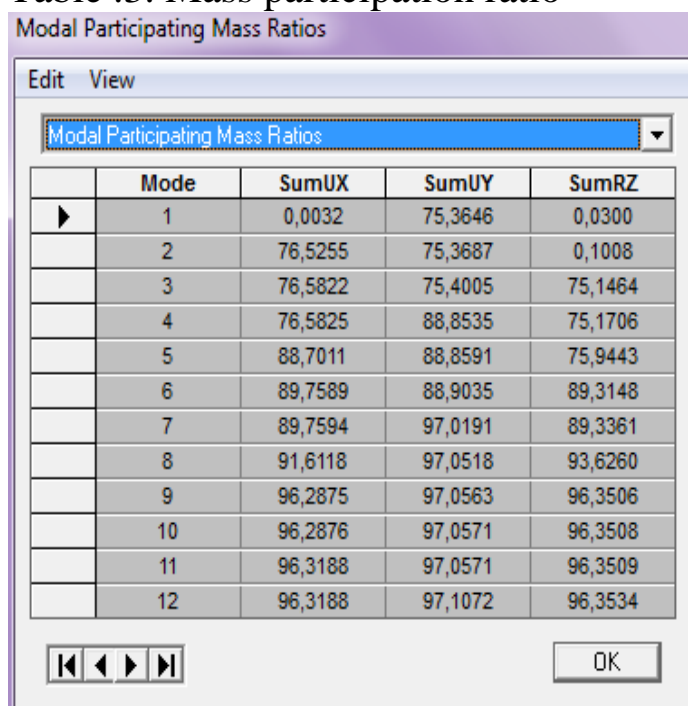

To simulate the random direction of the earthquake effect on the building structure, the effect of earthquake loading in the main direction specified in SNI 03-1726-2002 article 5.8.1 must be considered $100 \%$ effective and must be considered to occur simultaneously with the effect of earthquake loading in the perpendicular direction on the main direction of loading earlier, but with an effectiveness of only $30 \%$.

12.6.3.3 SNI 1726-2012 Analysis of the response spectrum used to determine the total planned displacement and total maximum displacement must include a model that is vibrated simultaneously (100 percent) by ground motion in the critical direction and 30 percent ground motion in the perpendicular direction, in the direction horizontal. The maximum displacement of the isolation system must be calculated as the sum of the orthogonal displacement vectors from these two directions.

From the dynamic analysis carried out we get shear forces on each floor as shown in table 4 below this. 
Table 4. Dynamic floor shear force distribution response spectrum (units kgf-m)

\begin{tabular}{llll}
\hline Story & Load & VX & VY \\
\hline Roof & SPECX & $14,523,990$ & 153,500 \\
Roof Floor & SPECX & $124.283,180$ & $1.037,600$ \\
Fl.4 $^{\text {th }}$ & SPECX & 212,508940 & $1.301,440$ \\
Fl.3 $^{\text {rd }}$ & SPECX & $270,588,070$ & $1.683,160$ \\
Fl.2 $^{\text {nd }}$ & SPECX & $299,560,910$ & $2.108,650$ \\
Roof & SPECY & $14,523,990$ & 153,500 \\
Roof Floor $^{\text {th }}$ & SPECY & $124.283,180$ & $1.037,600$ \\
Fl.4 $^{\text {th }}$ & SPECY & 212,508940 & $1.301,440$ \\
Fl.3 $^{\text {rd }}$ & SPECY & $270,588,070$ & $1.683,160$ \\
Fl.2 $^{\text {nd }}$ & SPECY & $299,560,910$ & $2.108,650$ \\
\hline
\end{tabular}

The ground shear force results of dynamic analysis need to be corrected by a scale factor to the static basic shear force obtained from the first vibratory range of the structure if the value is less than 0.8 times the static basic shear force. The magnitude of the basic shear force $\mathrm{V}$, according to the equivalent static analysis is

$\mathrm{V}=\frac{\mathrm{C}_{1} \mathrm{~W}}{\mathrm{R}} \mathrm{V}=\mathrm{C}_{1} . \mathrm{W} \quad \mathrm{Cs}=\frac{\mathrm{S}_{\mathrm{DI}} \mathrm{I}}{\mathrm{R}}$

$\mathrm{Cs}<\underline{\mathrm{S}}_{\mathrm{D} 1} \mathrm{I} . \quad \mathrm{C}_{1}=1,4$ for $\mathrm{S}_{\mathrm{D} 1}=0.3-0.4$ TR

where $\mathrm{C}_{1}$ is the earthquake response factor value obtained from the earthquake response spectrum plan according to the fundamental natural vibrational time of $\mathrm{T} 1$.

After knowing the nominal basic shear load $\mathrm{V}$ that will occur in buildings when an earthquake takes place, then the horizontal force distribution of the earthquake along the height of the building and the planned earthquake load will be calculated by all building structure components being modeled. In principle, all nominal shear forces will be divided into each floor of the building by distributing the force based on the portion of the floor's weight and height. Distributed loads work at the center of mass of the floor. For this reason, the formula used is:

$\mathrm{F}_{\mathrm{x}}=\mathrm{C}_{\mathrm{vX}} \mathrm{V}$ at 7.8.3 SNI 1726-2012

$\mathrm{F}_{\mathrm{x}}=\frac{\mathrm{W}_{\mathrm{i}} \mathrm{z}_{\mathrm{i}}}{\sum_{\mathrm{i}=1}^{\mathrm{n}} \mathrm{W}_{\mathrm{i}} \mathrm{z}_{\mathrm{i}}} \mathrm{V}$

where $\mathrm{Wi}$ is the weight of the i-level floor, including the corresponding live load, $\mathrm{Zi}$ is the $\mathrm{i}$-level floor height measured from the lateral clamping level, while $\mathrm{n}$ is the toplevel floor number.In this case, $\mathrm{T}_{1}$ is 1.1178 seconds, the value of $\mathrm{R}$ (table 9. $E_{2}$ at SNI 1726-2012) is taken 6.5 and the weight of the Wi floor is obtained from calculations using the ETABS program. Table.5. summarizes the results of calculations that will produce $\mathrm{Fi}$ values on each floor.

Table 5. Static floor shear force distribution is equivalent

\begin{tabular}{lllll}
\hline \multirow{2}{*}{ Floor } & $\mathbf{W i}$ & Wi.zi & Fi & Vi \\
\cline { 2 - 3 } \cline { 5 - 6 } & $\mathbf{( K g f )}$ & & $\mathbf{( k g f )}$ & $\mathbf{( k g f )}$ \\
\hline Roof & 83,1345 & $1.554,6152$ & 160,4747 & 160,4747 \\
Roof & 717,1968 & $11.475,1488$ & $1.184,5193$ & $1.344,9940$ \\
Floor & & & & \\
Fl.4 $^{\text {th }}$ & 736,9678 & $8.843,6138$ & 912,8797 & $2.257,8737$ \\
Fl.3 $^{\text {rd }}$ & 749,8678 & $5.998,9424$ & 619,2393 & $2.877,1130$ \\
Fl.2 $^{\text {nd }}$ & $1.008,8383$ & $4.035,3532$ & 416,5483 & $3.293,6613$ \\
\hline$\sum$ & $3.296,0052$ & $31,907,6732$ & - & $3.293,6613$ \\
\hline
\end{tabular}

Furthermore, to get the nominal level shear force distribution due to the effect of the planned earthquake along the building's height which is more conservative, because in this case the basic shear force for the $\mathrm{x}$-direction and $y$-direction from dynamic analysis is less than $80 \%$ of the static analysis results, need to be recalculated by taking into account the scale factor

$$
\begin{aligned}
& \frac{0,8 V_{s t}}{V_{x}} \text { ( for } X \text { direction earthquake) } \\
& \text { and }
\end{aligned}
$$


$\frac{0,8 V_{\text {st }}}{V_{\mathrm{y}}}$ (for Y-direction earthquake)

The results of correction of dynamic floor shear force distribution can be seen in table 6 . for the $\mathrm{x}$-direction and table 7.for $y$-direction.

Table 6. Scaled x-direction response spectrum analysis table

\begin{tabular}{|c|c|c|c|c|}
\hline Floor & $\begin{array}{l}\begin{array}{l}0.8 \mathrm{Vi} \\
\text { (kgf) }\end{array} \\
\end{array}$ & $\begin{array}{l}\text { VX } \\
\text { (kgf) }\end{array}$ & $\begin{array}{l}\begin{array}{l}\text { Scaled VX } \\
\text { (kgf) }\end{array} \\
\end{array}$ & $\begin{array}{l}\mathrm{Fi} \\
\text { (kgf) }\end{array}$ \\
\hline Roof & 128,380 & $14.523,990$ & $14.523,990$ & $14.523,990$ \\
\hline $\begin{array}{l}\text { Roof } \\
\text { Floor }\end{array}$ & $1.075,995$ & $124.283,180$ & $124.283,180$ & $109.759,190$ \\
\hline Fl. $4^{\text {th }}$ & $1.806,299$ & $212,508,940$ & $212,508,940$ & $88.225,760$ \\
\hline Fl. $3^{\text {rd }}$ & $2.301,690$ & $270.588,070$ & $270.588,070$ & $58.079,130$ \\
\hline Fl. $2^{\text {nd }}$ & $2,634,929$ & $299.560,910$ & $299.560,910$ & $28.972,840$ \\
\hline
\end{tabular}

Table 7. Scaled y-direction spectrum response analysis table

\begin{tabular}{lllll}
\hline Floor & $\begin{array}{l}\mathbf{0 . 8 V i} \\
(\mathbf{k g f})\end{array}$ & $\begin{array}{l}\text { VY } \\
(\mathbf{k g f})\end{array}$ & $\begin{array}{l}\text { Scaled VY } \\
(\mathbf{k g f})\end{array}$ & $\begin{array}{l}\text { Fi } \\
(\mathbf{k g f})\end{array}$ \\
\hline Roof & 128,380 & 153,500 & 214,900 & 214,900 \\
Roof & $1.075,995$ & $1.037,600$ & $1.452,640$ & $1,237,740$ \\
$\begin{array}{l}\text { Floor } \\
\text { Fl.4 }\end{array}$ & $1.806,299$ & $1.301,440$ & $1.822,016$ & 369,376 \\
$\mathbf{F l . 3}^{\text {rd }}$ & $2.301,690$ & $1.683,160$ & $2.356,424$ & 534,408 \\
Fl.2 $^{\text {nd }}$ & $2,634,929$ & $2.108,650$ & $2.952,110$ & 595,686 \\
\hline \multicolumn{5}{l}{ Scale factor of force shear=1,4 } \\
\hline
\end{tabular}

Graph of shear force comparison between 0.8 times the equivalent static and $\mathrm{x}$-direction spectrum response can be seen in Figure 9, while between 0.8 times the equivalent static and y-direction spectrum response can be seen in Figure 10

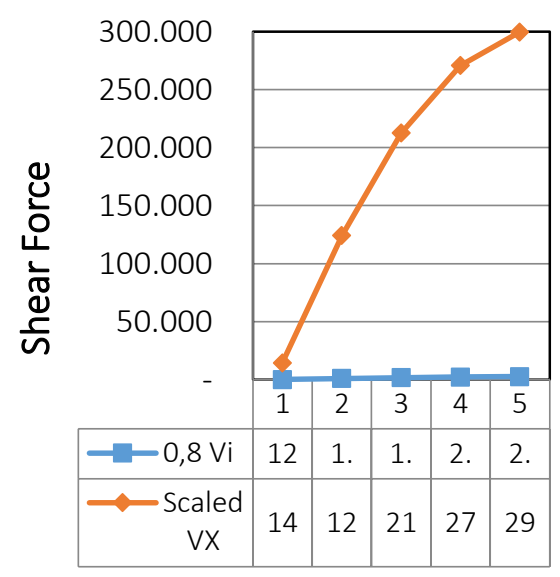

Figure 9 Comparison graph between $0.8 \mathrm{Vi}$ and Scaled VX

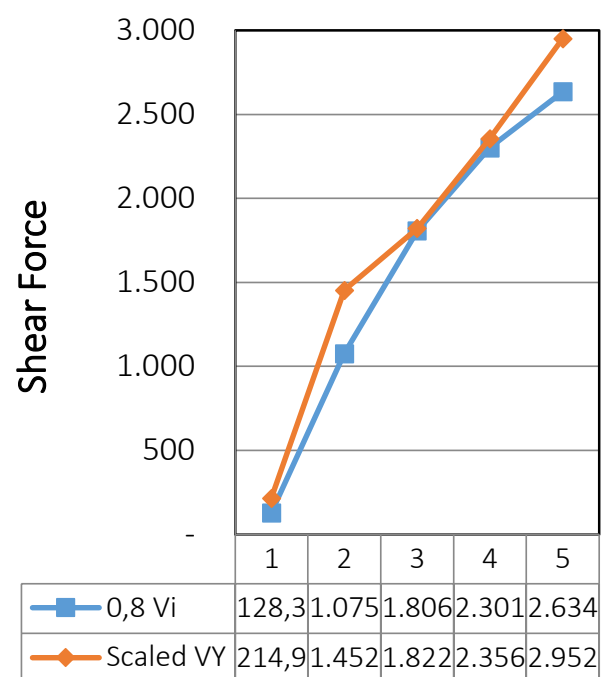

Figure 10. Comparison graph between $0.8 \mathrm{Vi}$ and Scaled VY

\section{Displacement of the Center of} Mass and Inter-Level Deviation Deviation between levels from a point on a floor is determined as the horizontal deviation of that point relative to the corresponding point on the floor below. The results of displacement at the center of mass of the structure and the value of the inter-floor deviation are obtained after a structural analysis is carried out for the corrected earthquake load (planned earthquake load). The displacement value of the structure at each center of mass can be seen in table 8 . and the drift value for $\mathrm{x}$ direction and $y$-direction earthquake loads can be seen in table 9. and table 10.

Table .8. Displacement at the center of mass of the floor (unit $\mathrm{cm}$ )

\begin{tabular}{lllll}
\hline \multicolumn{5}{l}{ Diplacement at Diaphragm Center of Mass } \\
\hline Story & Load & VX & UY & RZ \\
\hline Roof & SPECX & 3,9539 & 0,0251 & 0,00009 \\
Roof Floor & SPECX & 3,7301 & 0,0243 & 0,00008 \\
Fl.4 $^{\text {th }}$ & SPECX & 2,9833 & 0,0195 & 0,00005 \\
Fl.3 $^{\text {dd }}$ & SPECX & 1,8690 & 0,0127 & 0,00005 \\
Fl.2 & SPECX & 0,6264 & 0,0046 & 0,00004 \\
Base & SPECX & 0,0000 & 0,0000 & 0,00000 \\
Roof & SPECY & 3,9539 & 0,0251 & 0,00009 \\
Roof Floor & SPECY & 3,7301 & 0,0243 & 0,00008
\end{tabular}




\begin{tabular}{lllll} 
Fl.4 $^{\text {th }}$ & SPECY & 2,9833 & 0,0195 & 0,00005 \\
Fl.3 $^{\text {rd }}$ & SPECY & 1,8690 & 0,0127 & 0,00005 \\
Fl.2 $^{\text {nd }}$ & SPECY & 0,6264 & 0,0046 & 0,00004 \\
Base & SPECY & 0,0000 & 0,0000 & 0,00000 \\
\hline
\end{tabular}

Table .9. Deviation ratio between maximum levels of $\mathrm{x}$-direction

\begin{tabular}{llllll}
\hline Story & Point & X & Y & Z & DriftX \\
\hline Roof & 825 & 2280 & 0 & 1870 & 0.00083 \\
Roof Floor & 534 & 750 & -700 & 1600 & 0,00227 \\
Fl.4. $^{\text {th }}$ & 817 & 980 & 0 & 1200 & 0,00286 \\
Fl.3 $^{\text {rd }}$ & 817 & 980 & 0 & 800 & 0,00310 \\
Fl.2 $^{\text {nd }}$ & 41 & 1800 & 1950 & 400 & 0,00169 \\
\hline
\end{tabular}

Table 10. Deviation ratio between maximum levels of y-direction

\begin{tabular}{llllll}
\hline Story & Point & X & Y & Z & DriftY \\
\hline Roof & 29 & 2460 & 720 & 1870 & 0,00005 \\
Roof Floor & 16 & 3600 & 720 & 1600 & 0,00026 \\
Fl.4 $^{\text {th }}$ & 16 & 3600 & 720 & 1200 & 0,00019 \\
Fl.3 $^{\text {rd }}$ & 722 & 3725 & 720 & 800 & 0,00012 \\
Fl.2 $^{\text {nd }}$ & 727 & -125 & 620 & 400 & 0,00019 \\
\hline
\end{tabular}

From the results of the analysis of deviations due to earthquake loading, the maximum deviation of $\mathrm{x}$-direction occurs on the 3rd floor and y-direction on the roof floor $\mathrm{X}$ and $\mathrm{Y}$ direction floor deviations are eligible. SNI 1736-2013 at 12.6.4.4 deviation limits

1.The maximum inter-floor deviation of the structure above the isolation system is calculated using response history analysis based on the deflection characteristics of the non-linear elements of the earthquake force retaining system not to exceed 0.020 hsx.

2 .Cross-floor deviation limits The maximum inter-floor deviation of structures above the insulation system must not exceed 0,015 hsx The deviation between floors must be calculated based on Equation 34 with a factor. The $\mathrm{CD}$ of the isolation system is the same as the RI factor specified in 12.5.4.2 SNI 1726-2012.

\section{Service Limit Performance}

The performance of service structure boundaries $(\Delta s)$ is determined by the intersection between levels due to the effect of the earthquake plan, which is to limit the occurrence of excessive melting of steel and concrete cracking, in addition to preventing non-structural damage and discomfort to occupants. The deviation between these levels must be calculated from the deviation of the building structure due to the effect of nominal earthquake which has been multiplied by the scale factor.

According to SNI 03-1726-2002 article 8.1.2, the performance of service limits must not exceed:

$\Delta_{\mathrm{s}}<\frac{0.03}{\mathrm{R}} \times \mathrm{h}_{\mathrm{i}}$ or $30 \mathrm{~mm}$ (smallest)

$\Delta_{s}<\frac{0,03}{6,5} \times 4000$

$=18,4615 \mathrm{~mm}$ for high floor $4 \mathrm{~m}$

$\Delta_{s}<\frac{0,03}{6,5} \times 2700=12,4615$

$=12.4615 \mathrm{~mm}$ for high floor $2,7 \mathrm{~m}$

for a $2.7 \mathrm{~m}$ high level where:

$\mathrm{R}=$ earthquake reduction factor of

6.5

$\mathrm{h}_{\mathrm{i}}=$ the relevant level is $4 \mathrm{~m}$ and 2.7 $\mathrm{m}$ (roof)

The deviation ratio between maximum levels for $\mathrm{x}$-direction and $y$-direction can be seen again in table 9 . and 10. above.

$\mathrm{X}$-direction $\Delta \_3=0.00310 \times 4000=$ $12.4 \mathrm{~mm}<18.4615 \mathrm{~mm} \rightarrow$ allright Y-direction $\Delta_{\text {roof }}=0,00026 \times 4000$ $=1.04 \mathrm{~mm}<18.4615 \mathrm{~mm} \rightarrow$ allright

14. Ultimate Boundary

Performance The ultimate performance limit $(\Delta \mathrm{m})$ of a building structure is determined by the deviation between the maximum level of a building structure on the 
verge of collapse, which is to limit the possibility of structural collapse that can cause casualties. Deviations $(\Delta s)$ and intersections between levels $(\Delta \mathrm{m})$ must be calculated from deviations of building structures due to nominal earthquake loading, multiplied by a multiplier factor. Multiplier factors based on SNI 031726-2002 article 8.2.1 for irregular buildings:

$\xi=0.7 \mathrm{R} /$ (Scale Factor)

$\Delta \mathrm{m}=\xi \Delta \mathrm{s}$

To meet the ultimate building boundary performance requirements, in all cases the deviation between building structures according to SNI 17362013 at

12.6.4.4 deviation limits may not exceed:

$0.02 \times$ hi $=0.02 \times 4000=80 \mathrm{~mm}$ for floors with hi $=4 \mathrm{~m}$

$0.02 \times$ hi $=0.02 \times 2700=54 \mathrm{~mm}$ for floors with $\mathrm{hi}=2.7 \mathrm{~m}$

The scale factor for the $\mathrm{x}$-direction spectrum response can be seen again in table .6 and the y-direction in table 7 .

The $\mathrm{x}$-direction scale factor $=1$

Figure 11 until figure 13 shows the results of a 3-dimensional run. Whereas figures 14 through 17 show differences in column design, reinforced by consultants and writers based on the threedimensional structure program

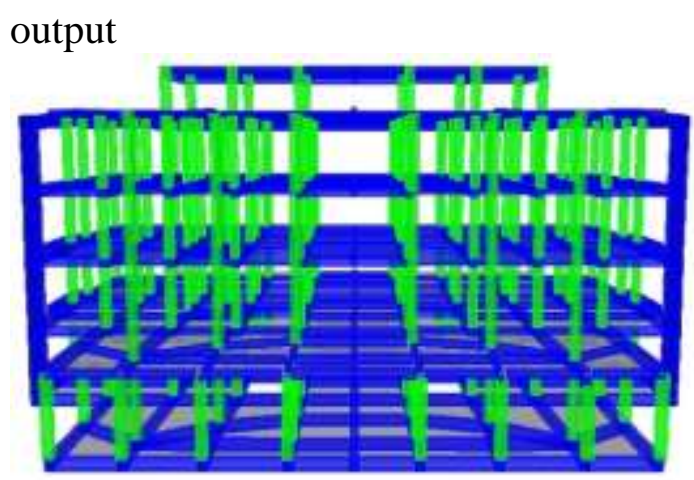

Figure 11. Front View of Structure Modeling

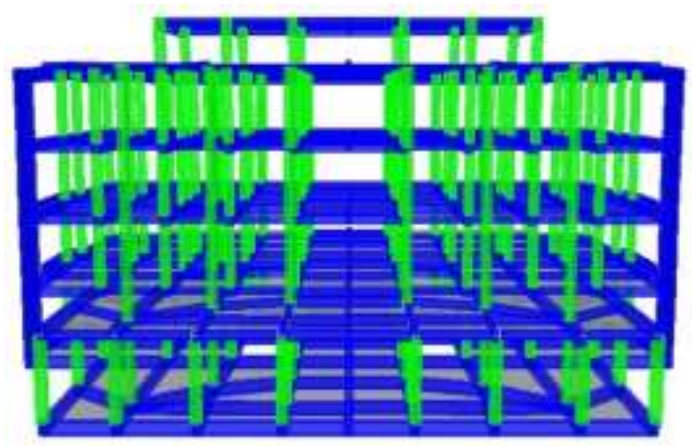

Figure 12. Back View of Structure Modeling

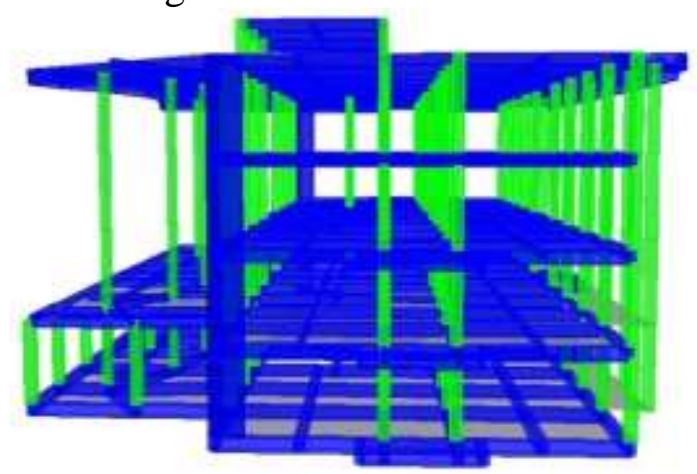

Figure 13. Side View 


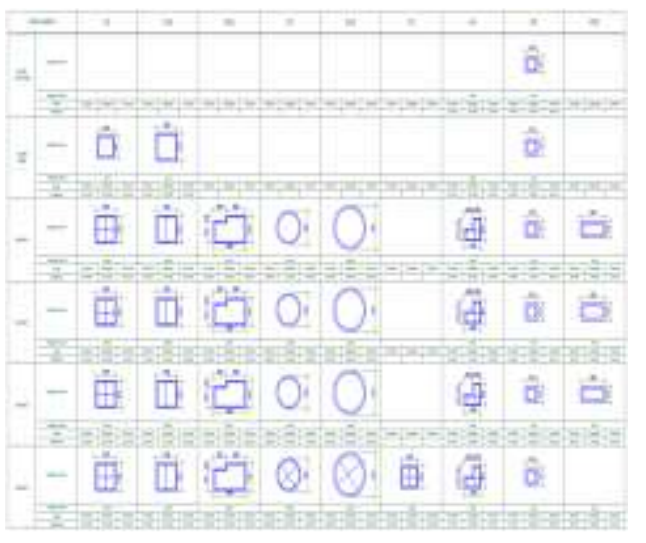

Figure 14. The column design is determined by the author according to the needs of the structural stiffness

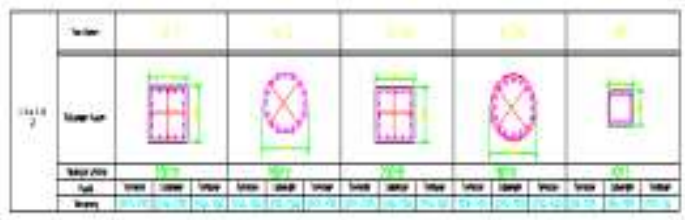

Figure 15. Column design for all floors with dimensions and reinforcement by structure consultant

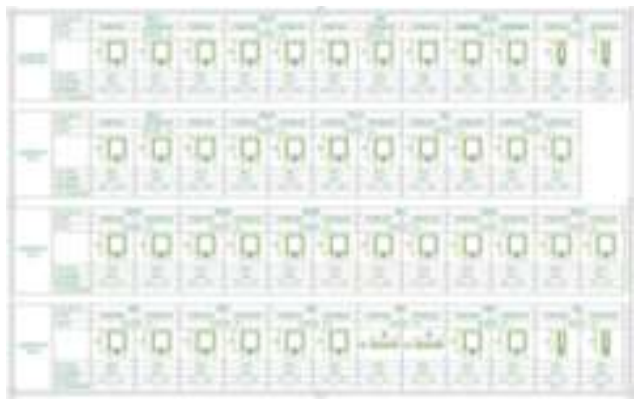

Figure 16. Dimension and reinforced beam design by Author

Figure dimension and reinforced beam design by Structure Consultant can be seen on appendix.

\section{Analysis Reinforced Column and Beam}

From the structure consultant still twisted in shape mode 1 and 2 made changes according to table 1. The difference in design of vertical elements (columns, shear walls) is significant. If the horizontal dimensions elemen and reinforcement are not much different.. The dimensions of the beam don't change much, only a few bones change insignificantly, because the column is affected by twisting

- Concrete quality $\mathrm{f}^{\prime}=24,9 \mathrm{mpa}$

- Reinforced quality $\mathrm{f}_{\mathrm{y}}=400 \mathrm{mpa}$

- Reinforced quality for stirrup $\mathrm{f}^{\prime}$ ys $=\quad 240 \mathrm{mpa}$

Based on SNI 03-2847-2013 article 7.6.1, the minimum net space between reinforcing bars which are parallel in a layer must be $\mathrm{db}$, but not less than $25 \mathrm{~mm}$. Article 10.9.1 The area of the longitudinal reinforcement, Ast, for components of non-composite compressive structures shall not be less than $0.01 \mathrm{Ag}$ or more than 0.08Ag.

By knowing the axial force acting on the base of the column, the maximum ultimate moment and the maximum shear at the bottom, and the percentage of rebar obtained from the analysis using the ETABS program, the number of main reinforcement and crossing / shear reinforcement required by the column. The steps for column reinforcement in the ultimate manner are as follows:

$$
\begin{aligned}
& \mathrm{P}^{\prime}{ }_{\mathrm{u}}=\frac{\mathrm{d}^{\prime}}{\mathrm{h}} \cdot \mathrm{f}^{\prime}{ }_{\mathrm{c}} \cdot \mathrm{Ag} \\
& \mathrm{P}^{\prime}{ }_{\mathrm{u}}=\frac{5}{50} \cdot 254,929 \cdot 50 \cdot 50 \\
& \mathrm{P}^{\prime}{ }_{\mathrm{u}}=63732,25 \mathrm{~kg} \\
& \mathrm{Pu}(50739,230)<\mathrm{P}{ }^{\prime} \mathrm{u}(63732.25), \\
& \text { then based on the provisions } \\
& \text { contained in SNI 03-2847-2002 } \\
& \text { article } 11.3 .2 .2, \text { a strength } \\
& \text { reduction factor } \phi \text { of } 0.8 \text { is taken. }
\end{aligned}
$$

Article 10.2.7.3 For $\mathrm{fc}$ between 17 and $28 \mathrm{MPa}, 1$ must be taken at 0.85 . For 
fc above $28 \mathrm{MPa}, 1$ must be reduced by 0.05 for each excess strength of 7 MPa above $28 \mathrm{MPa}$, but 1 must not be taken less than 0.65 .

Article 7.10.5 $P_{n \max }=0,8 \varnothing[0$, $85 \mathrm{fc}\left(A_{g}-A_{s t}\right) f_{y} A_{s t}$

Article 10.3.7 Structure components that are loaded with axial compressions must be designed against the maximum moments that may accompany axial loads. The factored axial load of $\mathrm{Pu}$ with existing eccentricities must not exceed the value given in 10.3.6. Your maximum factored moment must be enlarged to account for the effect of slenderness in accordance with 10.10.

Summary column dimensions, vertical and horizontal reinforced according to table 11

Table 11. Differences in design Column structure of consultant and author

\begin{tabular}{|c|c|c|c|}
\hline Col & $\begin{array}{l}\text { Structure } \\
\text { Consultant }\end{array}$ & Author & Changes \\
\hline K1 & $\begin{array}{l}\text { All as } \\
1,2 \mathrm{~A}, 3 \mathrm{~A}, 4 \mathrm{~A}, \\
\text { C except } \\
\text { C5,C6. } \\
500 \times 500 \\
20 \mathrm{D} 19 \text { no } \\
\text { cossing } \\
\text { horizontal } \\
\text { reinforcing }\end{array}$ & $\begin{array}{l}\text { similar } \\
\text { 500x500 } \\
\text { 20D19 } \\
(10-1)\end{array}$ & $\begin{array}{l}\text { 500x500 similar } \\
\text {,add crossing : } \\
\text { horizontal } \\
\text { reinforced }\end{array}$ \\
\hline $\begin{array}{l}\mathrm{K} 1 \\
\mathrm{~A}\end{array}$ & $\begin{array}{l}\text { 5A,6A,5B,6 } \\
\text { B,5C,6C, } \\
500 \times 500 \\
20 \mathrm{D} 19 . \text { no } \\
\text { cossing } \\
\text { horizontal } \\
\text { reinforcing }\end{array}$ & $\begin{array}{l}\text { similar } \\
500 \times 500 \\
20 D 19\end{array}$ & $\begin{array}{l}500 \times 500, \text { add } \\
\text { crossing : } \\
\text { horizontal } \\
\text { reinforced }\end{array}$ \\
\hline $\begin{array}{l}\text { K1 } \\
\text { B }\end{array}$ & $\begin{array}{l}500 \times 500 \\
20 D 19 \\
\text { stirrup Ø10- } \\
100\end{array}$ & $\begin{array}{l}1 \mathrm{D}, 10 \mathrm{D} \\
800 \times 500 \\
22 \mathrm{D} 19 \\
\text { horizontal } \\
\text { reinforced } \\
\text { D10-100 } \\
\end{array}$ & Add shear wall \\
\hline $\mathrm{K} 2$ & $\begin{array}{l}\text { D’ dia. } 600 \\
18 \text { D19, no } \\
\text { cossing } \\
\text { horizontal } \\
\text { reinforcing }\end{array}$ & $\begin{array}{l}\text { Idem } \\
\text { dia.600 } 18 \\
\text { D19 }\end{array}$ & $\begin{array}{l}\text { Similar ,add } \\
\text { crossing : } \\
\text { horizontal } \\
\text { reinforced }\end{array}$ \\
\hline $\begin{array}{l}\mathrm{K} 2 \\
\mathrm{~A}\end{array}$ & $\begin{array}{l}\text { All as } \mathrm{A}^{3} \\
\text { Curved } \\
\text { dia.600 } \\
18 \mathrm{D} 19, \text { no } \\
\text { cossing } \\
\text { horizontal } \\
\text { reinforcing }\end{array}$ & $\begin{array}{l}\text { dia.800. } \\
\text { 20D19 }\end{array}$ & $\begin{array}{l}\text { The diameter of } \\
\text { the column is } \\
\text { enlarged } \\
\text {,add crossing: } \\
\text { horizontal } \\
\text { reinforced }\end{array}$ \\
\hline K3 & $\begin{array}{l}\text { All as } A^{\prime}, A^{\prime \prime} \\
400 x 400 \\
20 D 19\end{array}$ & $\begin{array}{l}\text { Lift side } \\
\text { column } \\
400 \times 400 \\
16 \mathrm{D} 16\end{array}$ & $\begin{array}{l}\text { Add } 400 \times 400 \text {. } \\
\text { add crossing : } \\
\text { horizontal } \\
\text { reinforced }\end{array}$ \\
\hline K4 & $\begin{array}{l}400 \times 400 \\
18 D 19\end{array}$ & $\begin{array}{l}\text { All as A',A" } \\
\text { Column L } \\
400, \text { thick } \\
200 \text { 10D16 }\end{array}$ & $\begin{array}{l}\text { Add : hook } \\
\text { (horizontal } \\
\text { reinforced) }\end{array}$ \\
\hline $\mathrm{Kp}$ & $\begin{array}{l}150 \times 150 \\
4 \mathrm{D} 13 \text { each } \\
\text { wall is } 12 \mathrm{~m}^{2}\end{array}$ & $\begin{array}{l}\text { similar } \\
\text { 150x150;4 } \\
\text { D13 }\end{array}$ & \\
\hline $\begin{array}{l}\mathrm{Kp} \\
2\end{array}$ & & $\begin{array}{l}\text { Kp2 di as D } \\
150 \times 300 \\
4 \mathrm{D} 13\end{array}$ & Add 150x300 \\
\hline
\end{tabular}




\section{CONCLUSION}

The results of the review show that the building of the consultant's design did not meet the structural requirements, but there were significant changes, especially in the columns and added shear walls. With changes in columns and the addition of shear walls, the structure of the building does not twist in shape modes 1 and 2, so that it meets the requirements of strength, stiffness and stability. That is the role of design structure review before it is built.

In add stabilitation to the structure at the bottom of the stairs out the back direction is given a retaining wall, to overcome the horizontal direction of active soil pressure, ground water and surface water from the direction of the hill

\section{ACKNOWLEDGEMENT}

The authors thank the project owner team who helped bring the implementers, supervisors and collect design and implementation documents

The author is asked by the project owner to audit the structure of commercial buildings that operate 1 year, but have cracked. Structure design documents, implementation, as built drawings are very minimal, so it needs to be done again, soil excavation near the foundation, interviews with excecutor and supervisors to ensure the condition of the structure installed.

\section{REFERENCES}

National Standardization Agency. (2012). Procedures for planning earthquake resistance for building and non-building structures: SNI 03-1726-2012

ICS 91,120.25; 91,080.01.

National Standardization Agency. (2002). Earthquake Resilience

Planning Procedures for Buildings: SNI 03-1726-2002. Bandung.

Reddy B.R ,Rao M. V. (2015). Earthquake Resistant Design of a Building Using Shear Wall ISSN No: 2348-4845. International Journal \& Magazine of Engineering, Technology, Management and Research. A Peer Reviewed Open Access International Journal Volume No: 2 (2015), Issue No: 10 (October) pp 415-420.

Resmi R, Roja S.Y. (2016). A Review On Performance Of Shear Wall International Journal of Applied Engineering Research, ISSN 0973-4562 Vol. 11 No.3 (2016) Tech pp 369-372 (C) Research India Publications;http/www.ripublicat ion.com/ijaer.htm.

Triastuti N.S (2017) . Bore Pile Foundation Tall Building Closed in the Heritage Building. AIP Conference Proceedings 1903, $090003 \quad$ (2017) online: https://doi.org/10.1063/1.501160 6 . pp 090003-1_090003-6.

Venkatesh K ,Venkatd T. (2017) Study on Seismic Effect ff Building Shear Wall/Wall Without Shear Wall. International Journal of Civil Engineering and Technology (IJCIET). ISSN Print: 09766308 and ISSN Online: 0976 (C) IAEME Publication Scopus . Volume 8, Issue 1, January 2017, pp. 852-862.

Wang J. , Zhao H. (2018). High Performance Damage-Resistant Seismic Resistant Structural Systems for Sustainable and 
Resilient City: A Review Academic. Special Issue Resilient Civil Infrastructure under Dynamic Loadings. Review Article | Open Access Volume 2018 Article ID 8703697 | 32 pages | Published $30 \quad$ Apr 2018. https://doi.org/10.1155/2018/87 $\underline{03697}$ 


\section{Appendix}

BEAM TYPES OF $1^{\text {st }}$ and $2^{\text {nd }}$ FLOOR

\begin{tabular}{|l|l|l|}
\hline TMPE OFEEAM & \multicolumn{2}{|c|}{ B1 } \\
\hline POSMIION & END SPAN & MID SPAN \\
\hline EEAM & & \\
\hline & & \\
& & \\
& & \\
\hline UP REDFORC. & & \\
\hline LORENFORC. & & \\
\hline STRPLP & & \\
\hline SORENFORC & & \\
\hline
\end{tabular}

\begin{tabular}{|l|l|l|}
\hline TYPE OF BEMM & \multicolumn{2}{|c|}{ B2 } \\
\hline POSIIICN & END SPAN & MID SPAN \\
\hline BEAM & \multicolumn{2}{|c|}{$300 \times 600 \mathrm{~mm}$} \\
\hline & & \\
& & \\
\hline & & \\
\hline UP RENFORC. & & \\
\hline LO REINFORC. & & \\
\hline STIRRLP & & \\
\hline SO RENFORC. & & \\
\hline
\end{tabular}

\begin{tabular}{|l|l|l|}
\hline TYPE OF BEAM & \multicolumn{2}{|c|}{ B3 } \\
\hline POSITION & END SPAN & \multicolumn{1}{|c|}{ MID SPAN } \\
\hline BEAM & & \\
\hline & & \\
& & \\
\hline & & \\
\hline UP RENFCRC. & & \\
\hline LO REINFORC. & & \\
\hline STIRRUP & & \\
\hline SO REINFCRC. & & \\
\hline
\end{tabular}

\begin{tabular}{|l|l|l|}
\hline TYPE OF BEAM & \multicolumn{2}{|c|}{ B4 } \\
\hline POSTION & END SPAN & MID SPAN \\
\hline BEAM & \\
\hline & & \\
\hline & & \\
\hline & & \\
\hline UP RENFCRC. & & \\
\hline LO REINFORC. & & \\
\hline BTIRRUP & & \\
\hline SO RENFCRC. & & \\
\hline
\end{tabular}

\begin{tabular}{|c|c|c|}
\hline TYPE OF BEAM & \multicolumn{2}{|c|}{$\mathrm{B} 1 \mathrm{~A}$} \\
\hline POsinow & END SPAN & MID SPAN \\
\hline \multirow[t]{2}{*}{ BEAM } & \multicolumn{2}{|c|}{$25+459 \mathrm{~mm}$} \\
\hline & B. & B. \\
\hline UP RENFORC & 7219 & 3024 \\
\hline LO RENFORC. & 3019 & 4813 \\
\hline STIRRLP & uto-100 & $010-150$ \\
\hline SO RENFORC & - & - \\
\hline
\end{tabular}

BEAM TYPES OF $3^{\text {st }}$ and $4^{\text {nd }}$ FLOOR

\begin{tabular}{|c|c|c|}
\hline TYPE OF BEAM & \multicolumn{2}{|c|}{$\mathrm{B} 2 \mathrm{~A}$} \\
\hline POSIION & END SPAN & MID SPAN \\
\hline \multirow[t]{2}{*}{ BEAM } & \multicolumn{2}{|c|}{ acowitot $\mathrm{mm}$} \\
\hline & I & $=$ \\
\hline UP REINFORC. & sute & Fote \\
\hline LO REENFORC. & 3010 & sote \\
\hline STRRUP & $412-100$ & Dia.150 \\
\hline SD REINFOAC, & $=$ & - \\
\hline
\end{tabular}


Applied Research on Civil Engineering and Environment VOL. 02 NO. 01, August 2020

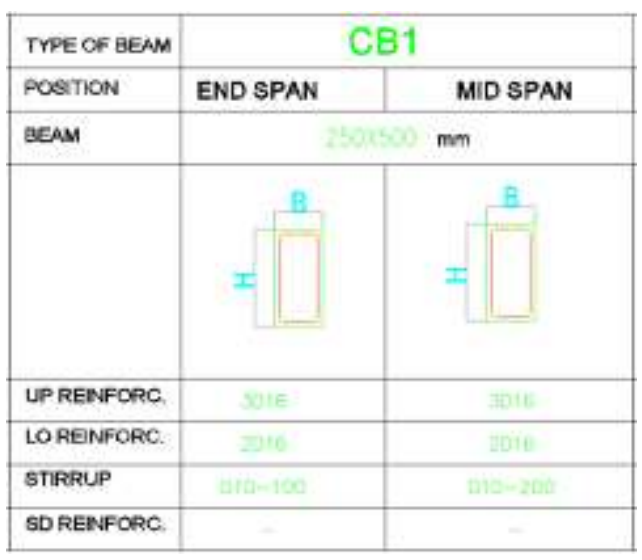

\begin{tabular}{|l|l|l|}
\hline TYPE OF BEAM & \multicolumn{2}{|c|}{ BL } \\
\hline POSMION & END SPAN & \multicolumn{1}{|c|}{ MID SPAN } \\
\hline BEAM & \multicolumn{2}{|c|}{ mm } \\
\hline & & \\
& & \\
& & \\
\hline
\end{tabular}

